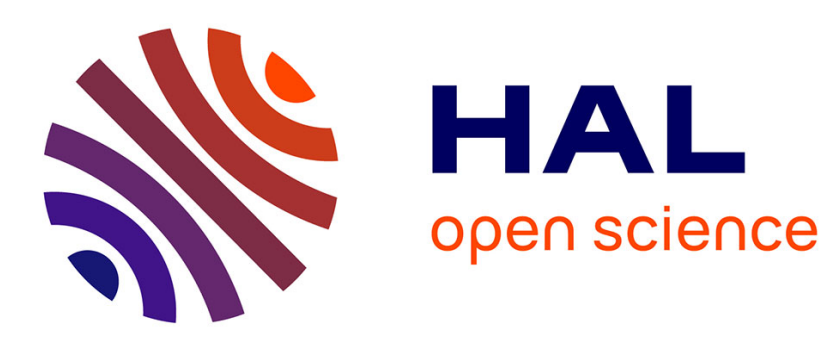

\title{
STEVENSON'S THE EBB-TIDE , OR VIRGIL'S AENEID REVISITED: HOW LITERATURE MAY MAKE OR MAR EMPIRES
}

Sylvie Largeaud-Ortega

\section{- To cite this version:}

Sylvie Largeaud-Ortega. STEVENSON'S THE EBB-TIDE, OR VIRGIL'S AENEID REVISITED: HOW LITERATURE MAY MAKE OR MAR EMPIRES. Victorian Literature and Culture, 2013, 41 (3), pp.561-593. 10.1017/S1060150313000107 . hal-02554065

\section{HAL Id: hal-02554065 \\ https://hal.science/hal-02554065}

Submitted on 2 Jul 2021

HAL is a multi-disciplinary open access archive for the deposit and dissemination of scientific research documents, whether they are published or not. The documents may come from teaching and research institutions in France or abroad, or from public or private research centers.
L'archive ouverte pluridisciplinaire HAL, est destinée au dépôt et à la diffusion de documents scientifiques de niveau recherche, publiés ou non, émanant des établissements d'enseignement et de recherche français ou étrangers, des laboratoires publics ou privés. 
Stevenson's The Ebb-Tide, or Virgil's Aeneid Revisited:

How Literature May Make or Mar Empires

By Sylvie Largeaud-Ortéga

Robert Louis Stevenson took it for granted that Rome had shaped most of the Western modern world: "the average man at home . . is sunk over the ears in Roman civilisation," he wrote in a letter to H. B. Baildon (Mehew 474). Unlike the English contemporaries of his own class, he had not been steeped in classical literature, nor had he "internalised Latin literature in the way he ascribed to his English character Robert Herrick . . . in The Ebb-Tide" - mostly because his poor health had precluded regular school attendance (Jolly, Stevenson in the Pacific 37). But he did come to the classics, "from the outside" as Roslyn Jolly demonstrates, through his legal studies: "Rome counted to him as something very much more than a literature - a whole system of law and empire" that had laid the foundations of most Western societies.

As a Scotsman, Stevenson viewed Rome as a boundary, a "Roman Wall" on either side of which stood two different civilisations (Jolly, Stevenson and Samoan History, 113-20). In the Pacific, he sensed he had quite radically crossed the boundary, which he inscribed in his very first travel notes:

I was now escaped out of the shadow of the Roman empire, under whose toppling monuments we were all cradled, whose laws and letters are on every hand of us, constraining and preventing. I was now to see what men might be whose fathers had never studied Virgil. (Stevenson, In the South Seas 9) 
Consequently, during the six and a half years that Stevenson spent in the Pacific (1888-94), he was a passionate participant observer ${ }^{1}$ of the "zones unromanised," a practice made famous by Bronislaw Malinowski some thirty years later (qtd. in Jolly, Stevenson in the Pacific 35). But he knew that, however long and thoroughly immersed in the Pacific, he and his fellow Westerners would remain products of the Roman empire:

He told a newspaper interviewer in Auckland in 1893, "You must remember that we are only the decayed fragments of the Roman Empire, from which we derive all that we value ourselves upon, and I believe that we can never be so well employed as in endeavouring to understand as well as we can the original meaning of things in whose ruins we live." (3536)

This paper suggests looking at Stevenson's last Pacific prose fiction, The Ebb-Tide ${ }^{2}$ (1894), from the multiple perspectives of the ancient Roman and the modern Western empires. Indeed, The Ebb-Tide may be read as a palimpsest ${ }^{3}$ of The Aeneid ( 29-19 BC), and more particularly of its sixth book, which narrates Aeneas's katabasis. ${ }^{4}$ Virgil's Aeneid was a founding text of the Roman Empire, and a favourite of Stevenson's. In a letter he wrote to Henry James from Honolulu in March 1889, he stated that the sixth book was a masterpiece Stevenson then had just sailed in from the secluded village of Tautira in Tahiti where, for over two months, The Aeneid and a Latin dictionary had composed his whole library. ${ }^{5}$ His cousin and biographer, Graham Balfour, confirms: "I am not sure that Virgil was not more to him than any other poet, ancient or modern" (102). The Ebb-Tide mentions or quotes The Aeneid no fewer than ten times, ${ }^{6}$ which produces, as Alan Sandison says, "a persistent echo" (330). I will not contradict Sandison's argument that "Virgil's voice remains one among many" in "a Marabar Cave of literary echoes" $(330,327)$. This holds true indeed when The Aeneid is taken solely as a literary influence. But I suggest approaching Virgil's work, as did Stevenson, also as a historical and cultural influence, a hallmark of Western civilisation. Indeed, in the first 
century BC, The Aeneid was commissioned by Caesar Augustus to eulogise the newlyenlarged Roman Empire. In the eighteenth and nineteenth centuries, it was used again by European empire-builders to account for their worldwide enterprises of expansion. From the Mediterranean to the Pacific, Virgil laid down the legendary foundations of empires.

Through a comparative literary study of the katabases in The Ebb-Tide and The Aeneid, combined with references to historical and cultural accounts of the Pacific, I suggest investigating the extent to which Stevenson's narrative resonates with echoes from, and variations on Virgil's. For that purpose, readers of this article will be engaged in a sort of cruise through time in the Mediterranean and, most of all, the Pacific. Herrick, the hero of The Ebb-Tide, will be shown to progress in the wake of Aeneas, but also in the wake of the eighteenth-century Discoverers who, themselves, figured they were in the wake of Aeneas. Starting from Papeete in Tahiti, this will generate an appraisal of the exotic city, assessing the evolution of its representations from the age of Enlightenment, through nineteenth-century conventional South Sea literature, to Stevenson's time. We will then proceed on to the other Pacific island that features in The Ebb-Tide, an island whose two names, "nemorosa Zacynthos" and New Island, testify to the fact that Rome and the eighteenth and earlynineteenth centuries do collide in this novel. Upon landing on this island, a number of questions will be met: how similar were Aeneas's landings in the Mediterranean to the Discoverers' in the Pacific and their literary heirs', and to Herrick's in the late nineteenth century? How comparable are the katabases in The Aeneid and The Ebb-Tide, and their attending approaches to imperialism, in terms of commerce, colonisation, and Christianity? To conclude this voyage in time, a detour to the twentieth century will present Herrick as an heir, no longer to Aeneas, but to an existentialist Sisyphus. The overall purpose of this cruise is to confirm a multiplicity of Stevenson's facets: the writer will be seen as a forerunner of existentialism, an anthropologist, and a "postcolonial writer" who calls for an end to both 
conventional antique-oriented South Sea representations, and Western quasi-colonialism in the Pacific (Jolly, "The Ebb-Tide and The Coral Island" 89). Indeed, contrary to Virgil's Aeneid, Stevenson's Ebb-Tide may aim at, not making, but marring empires.

\section{Aeneas, Herrick's alter ego}

The hero of The Ebb-Tide, Herrick, is a beachcomber in Tahiti, an utter destitute, and a Virgil buff whose unique possession is a copy of The Aeneid, which he clings to through thick and thin:

The Virgil, which he could not exchange against a meal, had often consoled him in his hunger. He would study it, as he lay with tightened belt on the floor of the old calaboose, seeking favourite passages and finding new ones only less beautiful because they lacked the consecration of remembrance. (124)

The Virgil is so important to the hero and to the omniscient narrator that the book is defined first in the narration, before the hero: "one . . had a tattered Virgil in his pocket" (124). While the hero is yet unidentified, the book he owns is identified by the antonomasia ${ }^{7}$ "a Virgil," a trope which personifies it: the book is seen as a synecdoche of its author. Hero and book thus made flesh look singularly alike: the Virgil is "tattered" and Herrick's "flimsy cotton clothes" have "run the gauntlet of the tropic showers." On the other hand, the antonomasia endows the book with a mythical and metatemporal dimension (Barthes 201). The larger-than-life book consequently seems to impose itself as a fundamental reference, an a priori part of and a first clue to the hero's identity. Readers are given access to the hero through Virgil, who precedes the hero in the chronologies of the narration and of literary and cultural history. These are early hints that the character of Herrick might be approached via The Aeneid. 
When Herrick's name is eventually unveiled, it is stated just once, in contrast with The Aeneid's, which in the same paragraph is mentioned three times, as if to confirm a relation of subordination from hero to book. Further down in the narrative, not only does Virgil delineate Herrick's identity, it also secures the hero's survival. It helps Herrick to overcome hunger, but also homesickness: "he would ... dip into The Aeneid, and . . visions of England would throng upon the exile's memory: . . . a phrase of Virgil speaks ... of English places and of the student's own irrevocable youth" (125). The Aeneid saves Herrick and the crew of the Farallone from fatal starvation: when lost in the Pacific, they miraculously land on an island whose name, "nemorosa Zacynthos," is a quotation from Virgil (202). In Papeete and, as will be argued, in the Tuamotu, Herrick also turns to sortes Virgilianae ${ }^{8}$ for help. He draws his epitaph from Virgil: "terque quaterque beati Queis ante ora partum," so that, as a whole, Aeneas may be said to be Herrick's underlying support in life and beyond, or his alter ego (144).

In this context, Herrick's closest (temporal) companion, captain Davis, may relate to characters from The Aeneid, too. In the outskirting prison of Papeete, Davis's "swift step" up to "the threshold of the cell" resonates like Mercury's, the herald of heaven, come "swift as the rushing blast ... with plumed foot, [to] the outskirting cabins of Carthage" (Virgil, IV: 59) $)^{9}$ to deliver a message from "the Omnipotent" (IV: 58). ${ }^{10}$ The American consul is a modern-time, local Jove or omnipotent deus ex machina to the beachcombers: "[Consul] offers it to me: 'Brown, will you ship captain and take [the Farallone] to Sydney?'” (147). Echoing Jove's "Let him sail!" (IV: 59), ${ }^{11}$ Davis exhorts Herrick: “. . you got to go; and that's a prophecy."

And as the man stood and shook through his great stature, he seemed indeed like one in whom the spirit of divination worked and might utter oracles. (150) 
Both Mercury's and Davis's reports from above summon the heroes to start at once in search of a more fruitful future, such as designed by "the fates" (IV: 61) $)^{12}$ in Virgil or "Destiny" (146) in Stevenson.

Davis's message may also echo Venus's initial entreaty for Aeneas to launch an expedition in the Mediterranean. Both make an apparition among city ruins set literally or metaphorically ablaze, and spur the hero to flight. Venus appears to Aeneas amidst the flames and nightly gloom of burning Troy: "“the glowing fires gave me light. . . My gracious mother, never erst so bright to my eyes, offered herself to my view, and in pure radiance flashed through the night"” (II: 31-32). ${ }^{13}$ The captain likewise "appear[s]" all "flushed" among the "wreckage" of "the old calaboose" while "the glow of the tropic afternoon stared into that shady place through door and window" (143-44). In order to convince the heroes to undertake their voyages, both appeal to family duties. Herrick has to metaphorically carry his father on his back to flee from a devastated town and try and build a better destiny for all: If you thought a cent about this father that I hear you talk of, or of that sweetheart you were writing to this morning, you would feel like me. You would say, What matters laws, and God, and that? My folks are hard up, I belong to them, I'll get them bread, or, by God! I'll get them wealth, if I have to burn down London for it. (149)

Davis replicates Venus:

My son, ... [w]ilt thou not rather look where thou hast left Anchises thy father under the burden of years - look whether Creüsa thy wife remain to thee, and Ascanius thy son? Round them all, on this hand and that, range the battalions of Greece. (II: 32$)^{14}$ Herrick and Aeneas are thus made to experience both the burden of the past and the demands of the future, and are called upon to represent a new age. Like his alter ego, Herrick first procrastinates. His tergiversations, "is there nothing else?," "We could never do that," "And 
the crew ?" (150-51) recall Aeneas staying "dumb and distraught," raking his mind "this way and that," asking Mercury: "What could [I] do?" (IV: 60). ${ }^{15}$ Finally, upon Mercury's, Venus's and Davis's urgings, the heroes of both The Aeneid and The Ebb-Tide agree to start or continue their sea epics.

Herrick's other companion and the third protagonist in The Ebb-Tide's trio, "dwarfish" Huish (127), may also offer a minor - and, indeed, dwarfed - variation on an impersonation of Mercury: he also acts as the envoy from above when he decides to deliver a fateful message to the owner of "nemorosa Zacynthos": "I'll give the letter" (244). His part, however, takes a flawed turn because Huish is a grossly uneducated man totally ignorant of any classical literature, who consequently runs foul of the Virgilian hypotext. Unlike Davis, who does not have any inkling of literary codes either, but acts upon the supreme authorities of the American Consul and of "Destiny," cabin steward Huish takes it upon himself to deliver a message he has been so bold as to dictate to his superior, captain Davis. He thus runs counter to the antique model. In that respect, he can only go amiss: it may be presumed that, because he so blaringly flouts the hypotextual pattern, it is the message of his own condemnation to Hell he actually delivers.

\section{Herrick sailing in the wake of Aeneas}

Davis's impersonation of Venus and the Cyllenean messenger heralds the trio's departure from Tahiti to start their katabasis. Just as Ulysses was not allowed to reach Ithaca before he had made a halt in Hell, nor Aeneas to reach Italy without visiting "the world of Shadows" (VI: 98), ${ }^{16}$ in the same way, Herrick is not to continue his sea epic without sojourning with the dead. 
As in The Aeneid, the route to the underworld is a winding one. When the Farallone leaves Tahiti, she starts a meandering voyage through the Pacific, reminiscent of Aeneas's initial wanderings through the Mediterranean. The Farallone falteringly keeps changing course, heading first north-west toward Australia, then north-east for Peru, tentatively west for Samoa, before finally lying to by some land which some will eventually call their home.

On their route to the underworld, the stages of Aeneas's and Herrick's initial sea progresses are strikingly similar. Firstly, Aeneas's father, Anchises, erringly directs the Dardan fleet to Crete, which is beset by "a wasting malady," and where "[p]art resigned the sweet breath of life, part still wearily dragged their plague-stricken frames" (III: 40). ${ }^{17}$ In Anchises's wake, Wiseman and Wisehart - who first commanded the Farallone and whose "heirs" (179) the trio are - misguidedly take the schooner to an equally ill-fated island:

Wiseman and Wisehart landed in a boat ... and from every here and there in the back parts of the settlement, Taveeta heard the sounds of island lamentation. ... [T]he Dangerous Archipelago had been swept that year from east to west by devastating smallpox. (169)

Secondly, right after leaving Crete, Aeneas and his followers must bear the brunt of a squall: a gloomy cloud halted overhead, fraught with night and tempest, and ocean was ruffled by the dark. Straight the winds rolled up the flood, the great waves arose, and we were scattered and flung over the waste of waters. Clouds invested the day, the drenched night blotted out the heavens. (III: 42) $)^{18}$

Right after he has heard the tale of Wiseman and Wisehart's "error" (III: 41), ${ }^{19}$ Herrick's progress is halted by a similar gale:

the sky was obscured with misty scud; and from the windward an ominous squall came flying by, broadening and blackening as it rose... . [T] he squall shouted aloud and fell, in 
a solid mass of wind and rain commingled, on the Farallone; and she stooped under the blow, and lay like a thing dead. (171-72)

Thirdly, there looms the threat of starvation. This fresh calamity is portended to Aeneas and his companions by a shrieking Harpy, "Celaeno, prophetess of evil" (III: 43). The "eldest of the Furies" casts on them "the curse of hunger": " "the sin of your onslaught on us shall constrain you to grind with your teeth your half-eaten boards!'”20 To Herrick and his companions, this same threat is commented upon by devilish Huish, whose strident fury may be compared to Celaeno's:

“W'y, weren't you 'owling for fresh tins every blessed day? 'ow often 'ave I 'eard you send the 'ole bloomin' dinner off and tell the man to chuck it in the swill-tub? And breakfast? Oh, my crickey! breakfast for ten, and you 'ollerin' for more ! . . You dror it mild, John Dyvis; don't 'andle me; I'm dyngerous.” (182-83)

Fourthly, there arises a peaceful-looking island: "nemorosa Zacynthos" in both The Aeneid (III: 270) and The Ebb-Tide (202).

Captain Davis conducting the Farallone through the labyrinthine Tuamotu Archipelago may now be compared to the ferryman Charon driving Aeneas on his bark through the spiralling Styx. The way the captain is portrayed while sailing - a "drooping, unbuttoned figure," "self-indulgen[t]" and "hoggish" (164-65), "his eyes glazed, his face deeply congested" (171) - distinctively evokes Virgil's rower: "a grim ferryman, ghastly and foul ... his chin an unkempt mass of hoariness, his glary eyes flame-shot, his squalid, knotted garb pendent from his shoulders" (VI: 96). ${ }^{21}$ On their circling courses, both Charon and Davis convey the damned ones to Hell. Davis's boast, "I'll make [this ship] a floating hell" (156), echoes Charon's: "Here is the world of Shadows, of Sleep, and of the slumberous Night: no body of the living my Stygian barque may receive!" (VI: 98). ${ }^{22}$ Herrick does condemn Davis 
for having ferried souls to the underworld before: "you drowned others, . . be damned" (172). All along his journeys, Charon is begged by the dead to be ferried across the Styx so that their torments may be ended: " take me with thee across the flood, that . . . at least I may find a haven of calm!"” (VI: 97). ${ }^{23}$ Likewise, under Davis’s captainship, Herrick yearns for the sea abyss to open up and for his torments to be terminated: "he clung in the weather rigging, exulting; he was done with life; and he gloried in the release" (172). Like Charon's bark, the Farallone is besieged by the dead: she is fraught with the memories of the deceased Wiseman and Wisehart, of the Sea Ranger's six drowned victims, and of little Adar, Davis's late daughter. They all seem hauntingly to exhort Herrick to join them into "the horror of that grave" (160). Charon-like Davis endeavours to ignore them, as is ironically hinted by a literal reading of the expression "dead reckoning" 24 :

To the dead reckoning which Herrick still tried to keep, [Davis] would pay not the least attention nor afford the least assistance.

"What do we want of dead reckoning?" he asked. (165)

Just as Herrick's identity may be delineated by Aeneas's, in the same way, his Pacific wanderings may be seen to follow in the wake of Aeneas's initial Mediterranean roamings. What is more, the Farallone, described as the "tattered schooner" (173), reflects Herrick's "tattered Virgil" (124), so the hero is made to shift from book to schooner and vice versa, as from one metaphorical vessel to the other. Herrick's katabasis seems to merge with the antique one. He who can quote Virgil offhand is made to duplicate Virgil's tale; he who knows his alter ego's adventures by rote now experiences them. The Farallone finally stops at "nemorosa Zacynthos," an island come out of the blue into the Pacific straight from The Aeneid. She drops anchor there as if into the heart of Virgil's epic. The island's owner, Attwater, allows bookish Herrick to land, challenging him thus: 
"Remember your first view of the island, and how it's only woods and woods and water; and suppose you had asked somebody for the name, and he had answered - nemorosa Zacynthos."

“Jam medio apparet fluctu!” exclaimed Herrick. "Ye gods, yes, how good!” (202) Quoting The Aeneid proves to be a scholarly password: it opens to the hero the doors of the island which is the setting of the The Ebb-Tide's second part or - to use an antique epic designation - second "Chant": "The Quartette" (187).

Inversely, because of their "cultural blank" (Naugrette 18), ${ }^{25}$ Davis and Huish are only doled chary access to the isle. This gives rise to a comical dialogue between Davis and Attwater. While the former vainly tries to gain access to the atoll, the latter, like Virgil's Sibyl, delivers cryptic answers:

"You were talking of charter," said [Davis].

"Was I?" said Attwater. "Well, let's talk of it no more at present."

"Your schooner is overdue, I understand?" continued the captain.

"You understand perfectly, Captain Brown," said Attwater; "thirty-three days overdue at noon today."

"She come and goes, eh? Plies between here and ... ?" hinted the captain.

"Exactly; every four months; three trips a year," said Attwater.

"You go in her, ever?" asked Davis.

"No, one stops here," said Attwater, "one has plenty to attend to."

"Stop here, do you?" cried Davis. "Say, how long?"

"How long, O Lord," said Attwater with perfect, stern dignity. "But it does not seem so," he added, with a smile.

"No, I daresay not," said Davis. "No, I suppose not. Not with all your gods about you, and in as snug a berth as this." (195) 
Attwater, the cryptic island's warder, obviously delights in confounding his plebeian interlocutor. Davis can only admit to his inability to read omens, even though they be from the entrails of fish or oysters:

"Was there a - was the fishing - would you call the fishing anyways good?"

"I don't know that I would call it anyways anything," said Attwater, "if you put it to me direct."

“There were pearls too?” said Davis.

"Pearls, too," said Attwater.

“Well, I give out!” laughed Davis, and his laughter rang cracked like a false piece. "If you're not going to tell, you're not going to tell, and there's an end to it." (195-96) Being able to refer to The Aeneid keeps open to readers the doors of an intertextual reading of The Ebb-Tide. With Virgil's text as a hypotext, The Ebb-Tide may be said to revisit the initial books of The Aeneid in other times and climes.

\section{The Aeneid and the myth of Tahiti}

Herrick, or, for that matter, Stevenson, was not the first traveller who would have seen his Pacific sailings and landings in the light of Aeneas's. So did the so-called Discoverers ${ }^{26}$ of the South Seas in the late eighteenth-century. Most of them were scholars steeped in the classics, and while circumnavigating the globe, they believed they were re-enacting the antique epics that had founded Western civilisation. Indeed, like Aeneas's, the fleets of Wallis, Bougainville, Cook, and Banks were in quest of a mythical land, the Terra Australia that, since Ptolemy, had been deemed necessary to provide the world its balance - a tectonic balance between North and South, and also, especially in the eighteenth-century, a moral balance to compensate for corrupt European societies. 
There is indeed a very close bond between The Aeneid and the Discoverers. Aeneas claiming Italy, and the Discovers claiming Pacific islands, expressed similar urges for imperialist conquests. ${ }^{27}$ The Aeneid was commissioned by Augustus Caesar to put a seal to his ruling of the Roman Empire: Virgil was to trace the origins of the Empire back to Homer's Iliad and testify that Aeneas's offspring was destined to govern the Roman world. Consequently, The Aeneid took up Aeneas's tale where The Iliad had left it, Virgil in the first century BC harping back to Homer's eighth-century BC. In the wake of the Iliad and Odyssey, The Aeneid thus laid down the legendary foundations of an Empire in the Mediterranean. Eighteen centuries later, European empire-building started extending as far as the Pacific, and British and French Discovers in their turn relied on The Aeneid to celebrate their nations' imperialist moves. The eighteenth century now harked back to the first century $\mathrm{BC}$ and the eighth $\mathrm{BC}$.

The epigraph to Louis-Antoine de Bougainville's Voyage around the World by the King's Frigate La Boudeuse and the Store Ship L'Étoile (1767-68), 1771, is, predictably, a quote from The Aeneid: “Lucis habitamus opacis, riparumque toros et prata recentia rivis incolimus" ${ }^{\prime 28}$ (Bougainville 6), ${ }^{29}$ having Tahitians echo the inhabitants of Virgil's underworld "Happy Groves" (VI: 104). ${ }^{30}$ Like the Discoverers who had named lands "New World" or "Acadia" (after the Arcadian idyllic place in Greek mythology), Bougainville named the island of Tahiti “New Cythera," after Venus's Mediterranean home. His presentation of Tahiti repeatedly transplants his readers from one mythical archipelago to another. A Tahitian girl's "celestial shape" greets the newcomers, appearing "like Venus to the Phrygian shepherd" (131). Over the isle, "worshipping" the goddess of love is said to "brook no mysteries" (138), and "[n]owhere else could one find such handsome sitters to paint Hercules and Mars" (153). Moreover, Tahiti has been spared the miseries of old age and diseases - "the weather is so wholesome that, despite our toil, nobody fell sick" (152), so "one would think oneself in the 
Elysian Fields" (150). The botanist on board, Philibert de Commerson, corroborates this new tale of the Happy Groves:

[New Cythera] is the only place on earth where men live without any vice or prejudice or need or dissension. Born under the most beautiful sky, fed with the fruit of a fertile untilled earth, ruled by fathers of a family rather than by kings, they know of no gods but Love. $(\mathrm{xx})^{31}$

Tahiti materialised as a mythical place come true, the "golden age" regained (150). While physically sailing forth through the seas, the scholars in Bougainville's expedition mentally sailed back through centuries. Their search for a new world took them to an antique world, and all they could see in Tahiti was not otherness but sameness, or the idealised reflection of their own selves. The Discovery was in fact a recovery, or the locus amoenus of a collective nostalgia for a world lost. Bougainville was the harbinger of Virgil's Happy Groves regained, the founder of the myth of Tahiti.

And yet, even by eighteenth-century standards, Bougainville did not discover Tahiti: fear of French competition had led the British government to despatch Wallis and Carteret in 1766 to search for the Terra Australia, and Wallis's Dolphin had dropped anchor in Tahiti in 1767, ten months before Bougainville's La Boudeuse and L'Étoile in 1768. Close upon their rudders followed Cook's Endeavour, in 1769. What made Bougainville's presentation of Tahiti preeminent, though, was that his botanist's and his own travel notes were published first. In 1769, Commerson's description of New Cythera (published by, of all bearers of news, the Mercure de France) made a public sensation, and sparked a collective craze which flared up in France in 1771, with Bougainville's Voyage, and in Britain in early 1772, with the Voyage's printed translation. Wallis's and Cook's reports came out only in 1773, and to add insult to injury, they were rewritten after the idyllic fashion set by Commerson and Bougainville, in order to satisfy their readers' phantasmagorias: the Court's official writer, 
Hawkesworth, was commissioned by the Admiralty to compile and revamp the notes of Byron, Wallis, Carteret, Cook, and Banks. Eager to achieve Bougainville's level of fame, Hawkesworth edited and abridged their notes and inserted his own lyrical commentaries, speaking in the names of the navigators. The end result ${ }^{32}$ was far remote from the originals. For instance, Wallis's account of the first half of his Tahitian stay, when the Dolphin was assailed by hundreds of natives and opened fire, is low-key compared to the second half, when Wallis is made by Hawkesworth to describe delightful and romantic encounters with the Tahitian Queen. The three-volume work was a blockbuster. In France and Great Britain, Tahiti was definitely held as a mythical place: Venus's home rediscovered, or Virgil's Happy Groves come alive. It continued to be so through the following century; as late as 1897 , “Sundowner”'s Rambles in Polynesia still reflected identical readers' expectations:

There is an air of happiness about everything in the South Pacific. The palm-trees rustle friendly greetings to the stranger; the birds and animals of the groves and jungles stand their ground as a stranger approaches, confident that no harm is coming to them. The islanders themselves are cordial, affectionate, and lovable, honest as the sun, and innocent as doves. ... The present denizens of the Polynesian archipelagos . . . are in their pristine simplicity, without vice, temper and waywardness. No women of any colour or kind are more beautiful or tender-hearted than theirs, no men on earth more modest or brave. . . The Polynesian men and women are great, big, lively babies, all mirth and innocence: a curse be on the head of the thoughtless or vicious European aggressor who does anything to stifle simple mirth or to pollute that sacred innocence. (Qtd. in Menikoff 147-49)

\section{The ebb-tide of the myth of Tahiti}

In its revisitation of The Aeneid, Stevenson's narrative breaks away from these antiqueoriented representations of the Pacific. In The Ebb-Tide, Tahiti is no longer a New Cythera, 
but a new city. Papeete has become "[one of] these flash towns" (30) which, according to Wiltshire in The Beach of Fales $\bar{a},{ }^{33}$ a young vahine ${ }^{34}$ should steer clear of - a far cry from Venus's home, indeed. In flat contradiction with Bougainville's views, Stevenson claims that the weather in Tahiti is unwholesome; it is a place of dearth, disease, and despair:

Drenched with rains, broiling by day, shivering by night, a disused and ruinous prison for a bedroom, his diet begged or pilfered out of rubbish heaps, . . . Herrick had known what it was ... to sink into the coma of despair. (126-27)

Here is Stevenson's description of late nineteenth-century Papeete bay:

Seen from the beach through the thin line of shipping, two objects stood conspicuous to seaward: the little isle, on the one hand, with its palms and the guns and batteries raised forty years before in defence of Queen Pomare's capital; the outcast Farallone, upon the other, banished to the threshold of the port, rolling there to her scuppers, and flaunting the plague-flag as she rolled. ... The exuberant daylight and the blinding heaven of the tropics picked out and framed the picture. (152)

What with guns and plague, the bay bears the marks of the West's so-called fatal impact. ${ }^{35}$ The canons are reminders of the 1844-46 French-Tahitian wars and of Queen Pomare IV's humiliating surrender. The Farallone's yellow flag epitomises the epidemics brought by the Discovers and their followers' vessels, and the ensuing decimations of island populations. Only the "exuberant daylight and the blinding heaven of the tropics [which] picked out and framed the picture" remind readers of a conventional idyllic setting - but it is only a frame to the exotic cliché: the canvass itself has vanished. Instead there hangs a glaringly realistic picture (Figure 12).

Contrary to conventional South Sea authors like Melville, Loti, or Stoddard, Stevenson expresses no elegiac nostalgia for bygone Happy Groves: his is no evocation of phantasms, but of the drab reality of Tahiti. The beachcombers ${ }^{36}$ are other symbols of a drastic departure 
from antique myths. Cast out "[a]t the far end of the town" (123), they may be said to impersonate otherness. ${ }^{37}$ In Part I of The Ebb-Tide, instead of the islanders being viewed as white men's idealised reflections in the fashion of Bougainville, the white protagonists may be viewed as the oppressed natives' reflections. This is a literal inversion of the antique cliché, or otherness with a vengeance. Realising that his Western readers cared little for his previous postcolonial depictions of the plight of far-away natives, Stevenson may have hoped to achieve better results here, by depicting the effects of crushing imperialism upon Others that are white. The victims of scathing white oppression in the Pacific are his readers' fellowwhites: a former Oxford student, an American father of a family and seafarer, a Cockney clerk. This may express the author's persistent wish to prompt his readers into reacting against imperialist abuse and, eventually, recognise the Pacific peoples' plights and rights. For that purpose, Stevenson details the effects of obnoxious white imperial-like arrogance in Tahiti:

[Herrick's] face [was] dark with blood, his knees trembling under him with the hysteria of rage. Presently ... he cast himself down, and groaned aloud, and ground his face into the sand.

"Don't speak to me, don't speak to me. I can't stand it," broke from him. . . . $[\mathrm{H}]$ alf an hour later ... Herrick still lay where he had flung himself. (138) The beachcomber epitomises the powerlessness of the dispossessed and the disrespected, akin to the natives' under white supremacy.

Tahiti has metamorphosed from Happy Groves into "Hell” (131) and the white trio's physical, mental, and social collapse in the first part of The Ebb-Tide bellies imperial claims to righteousness. In 1894, Stevenson longed for an end to abusive white hegemony in the Pacific:

Stevenson . . . increasingly came to endorse Samoan rule, Samoan culture, and Samoan ownership of land. As a result, at the same time as he himself was hoping he might be 
given a position of political responsibility, he worked hard to deflate the corrupting power of the foreign presence ... and encouraged Samoans to take more responsibility for their future. Moreover, at times, rather than set himself up as a superior who looks down upon the natives as "barbarous children," Stevenson was just willing to accuse his fellow westerners of being childlike, naïve, and uncivilized. (Colley 136-37)

The Ebb-Tide calls for the nineteenth-century imperialist surge to ebb away.

This notion of an ebb and flow - or rather, a flow and ebb - runs all through The EbbTide. After the flowing-in claims to white supremacy in the Pacific comes a time for Western hegemony to ebb away. After the flow of antique-like clichés comes a time for island representations to be laid bare. The opening lines of The Ebb-Tide illustrate such a flow-andebb movement. They insist on the South Sea setting, in seeming compliance with the locus amoenus - "in the Pacific, ... in these isles of plenty, ... Papeete, . . on the beach, ... the tiny pagan city. In the South Seas, ... on the mountains of Eimeo" - and are replete with pictures of flower-garlanded Tahitian singers and musicians (123-24). However, these opening lines prove to be a masterpiece in ambivalence and the readers' conventional expectations are only roused to be instantly crashed:

Throughout the island world of the Pacific, scattered men of many European races and from almost every grade of society carry activity and disseminate disease. Some prosper, some vegetate. Some have mounted the steps of thrones and owned islands and navies. Others again must marry for a livelihood. (123) This opening paragraph starts on a surging motion, and closes on a formal rendition of an ebbing wave: “And there are still others, less pliable, less capable, less fortunate, perhaps less base, who continue, even in these isles of plenty, to lack bread" (123). The "less . . , less . . , less ..., perhaps less" isocolon ${ }^{38}$ sounds like successive waves ebbing away from the beach. There is a balance between fantasy and fact to the rhythm of the anaphoric 39 "Some/Others," 
and this binary pace may be compared, indeed, to the motions of the tide. In the next paragraphs, Tahitians stir inland from the shore, then the narrative world ebbs back to the beach and beachcombers. A concluding sentence closes rhythmically again on an auxesis ${ }^{40}$ : "no thought of sleep, . . . no breakfast, . . . less dinner, . . . no supper at all” (124). The social depletion depicted here compares with the depletion of a beach at low tide.

Structurally, stylistically, and thematically, the whole novel follows, tide-like, the same binary scansion. In two parts are given two successive representations of the Pacific. One occurs at a time of "descent" (124) and "fall" (126) in the trio's lives; the other starts "with the return of the ebb" (188), "at the hour of flood" (189). One takes place in Tahiti, the other on "nemorosa Zacynthos"/"New Island." One is sordidly realistic ${ }^{41}$; the other is allegorical. One is situated in the 1880 s, the other, as will be argued later in this paper, occurs allegorically at the time of the Discoverers. In that respect, following its initial "Some/Others" oscillation, the palimpsestic Ebb-Tide may signal the ebbing away of a literary tradition that has been allowed by "some" to hold sway since Bougainville, and which "others" now try to replace with fresh representations.

\section{Herrick sailing in the wake of the Discoverers}

Consequently, this paper contends that The Ebb-Tide revisits The Aeneid's katabasis in order to challenge eighteenth- and nineteenth-century antique-oriented representations of the Pacific islands, and Western imperialism altogether. The Ebb-Tide echoes Virgil's katabasis, only to turn it on its head. Anchises's eulogy of an empire in the sixth book becomes scathing criticism of both cultural Euro-centrism and nineteenth-century Western imperialism. Unlike the Discoverers and their followers, Herrick questions the validity of the presence of white men in the Pacific. His Aeneas-like physical and moral wanderings illuminate a search for the 
grounds of Western cultural, economic, religious, and political empire-building in the southern archipelagos.

Since the Discoverers claimed they were following in the wake of Aeneas, then Herrick in the wake of Aeneas must be following the Discovers, too. Many things attest that the Farallone does sail back into the past. Herrick first senses so: "Suppose we were sent suddenly back" (160); at the wheel, he "st[ands] entranced, reviewing the past" (163) as if the schooner were being steered for times of yore. The analepsis ${ }^{42}$ becomes patent as soon as the Farallone perceptibly repeats the Sea Ranger's past: “[a] sharp report from the cabin startled him; a third bottle had been opened; and Herrick remembered the Sea Ranger" (167). This is confirmed by Huish: "I don't 'arf like it. It looks to me like the Sea Rynger over again" (167). The present merges into the past to such an extent that the schooner is engaged in a repetitive pattern: "You lost the Sea Ranger . . . Now you're going to lose the Farallone. You're going to drown here the same way as you drowned others" (172). Caught in this cyclical scheme, the Farallone also retraces her own history: under Davis's captainship she drifts aimlessly in the Tuamotu and hits at random upon an atoll devastated by small pox, just as she did under Wiseman and Wisehart. "I think [him] all-e-same Wise-a-mana" (168) says the crew about Davis. Indeed, on board the Farallone, one captain after the other sinks into drunkenness. They are similarly foul-mouthed. Their recklessness arouses the same dread in the native crew who, "seeing themselves lost on the huge deep with their insane conductors, ... had drunk deep of terror" (169) under Wiseman and Wisehart, before "clinging to the spokes with a face of a sickly blue" (172) under Davis. As a whole, it may be inferred that in labyrinthine Tumaotu the Farallone veers away from linear temporality, to wander off into the coiling mazes of the past and of History at large. No longer anchored in realistic Papeete, where the action is situated in the 1880 s, she freely slips back into several colliding past time levels. As 
drunk as her lord, she rolls on like a bateau ivre, and ebbs into an area outside time that seems to allow for all kinds of past temporality, or into what may be called some allegorical past.

In that context, it may be contended that the Farallone reaches back, not only to Roman times, but also to an age that mirrored Roman expansionism, the eighteenth century. She allegorically reproduces the Discoverers' journeys, retracing the voyages of the likes of the Dolphin, Boudeuse, and Endeavour. Indeed, after them, she searches for a land that is mythical, i.e. "negates all situation in History . . , evacuates what is real" (Eliade 21). ${ }^{43} \mathrm{We}$ have seen that she first heads for Australia, which is none other than the Discovers' elusive Terra Australia; then she steers for Peru, or the no less mythical El Dorado. The next phantasmagorial destination is the inaccessible "home, home" (163). They then head for "some other place" (180), and for Samoa, which prove just as impossible. The Farallone finally makes for utopia incarnate: "[t]he isle - the undiscovered, the scarce-believed in" (187). It has been named New Island by Western navigators, just as the Pacific islands were named New Cythera, New Zealand, New Caledonia, etc., by Discoverers. This suggests that New Island stands as a hyperonym ${ }^{44}$ of all Pacific islands. The island's other name, “nemorosa Zacynthos," has been given just as arbitrarily by a Western self-styled discoverer and landowner, Attwater. ${ }^{45}$ New Island/“nemorosa Zacynthos” is a Discoverer's dream come true. It mirrors the mythical lands that explorers had been in search for from time immemorial. It epitomises perfection: "never in his dreams had he beheld anything more strange and delicate" (187). At the close of the first part, just as happened to the Discoverers who claimed they had reached antiquity's shores, the trio has lost touch with reality. They land on an atoll that lies outside space and time, the paragon of a mythical and allegorical Pacific island.

I suggest that New Island is an allegory for the Pacific islands at the time of the Discoverers and their early followers. In the second part of The Ebb-Tide readers are 
transported to the heart of the most crucial stage in Pacific History, the time of the first prolonged contacts ${ }^{46}$ with the West, known as the time of contact or fatal impact. The Farallone leaves behind late-nineteenth-century Tahiti and, sailing back in time, ends up in what Tahiti might have looked like in the late eighteenth and early nineteenth centuries ${ }^{47}$ (Figure 13). Allegorically, this sea passage conveys readers from the disastrous effects of a century-long Western presence in the Pacific - urban Tahiti scarred by guns and epidemics to the beginnings of this presence - the apparently pristine New Island, only just settled by Attwater (Figure 14). One of The Ebb-Tide's underlying principles may be to ebb back to the origins of Western empire-building in the Pacific: from a gruesomely realistic description of the consequences of quasi-colonialism, the narration ebbs back to an allegorical exploration of the foundations of quasi-colonialism. On New Island, Attwater has established "a business, and a colony, and mission of [his] own" (204). An imperial trinity, he can be seen as the archetypal first trader, first settler, and first missionary.

\section{Arriving on New Island}

As the second part of The Ebb-Tide opens, the Farallone's infernal crossing seems to draw to a close. The schooner's thieves are seen gliding on what looks like Hell's main river, the Cocytus, a Styx affluent fed, precisely, by the tears of thieves:

The airs were very light, their speed was small; the heat intense. The decks were scorching underfoot, the sun flamed overhead, brazen, out of a brazen sky; the pitch bubbled in the seams, and the brains in the brain-pan. And all the while the excitement of the three adventurers glowed about their bones like a fever. They whispered, and nodded, and pointed, and put mouth to ear, with a singular instinct of secrecy, approaching that island under-hand like eavesdroppers and thieves; ... and through the roar of so many miles of breakers, it was a silent ship that approached an empty island. (188) 
As soon as they sail through the pass of "nemorosa Zacynthos," the "gates" of the Ocean Door suddenly swing open onto the Elysian Fields. The Farallone "swe[eps] eddying through the gates, ... into a wonder of watery and silken hues, and . . into the inland sea beyond" (189). At "the hour of flood," the voyagers are, like Virgil's and Bougainville, taken "across the flood" to reach "a haven of calm!" (VI: 97): "they came to the realms of joy - the pleasant lawns of the Happy Groves, and the seats of the Blest" (VI: 104). ${ }^{48}$

[The Farallone] floated on the bosom of the lagoon, and below, in the transparent chambers of waters, a myriad of many-coloured fishes were sporting, a myriad pale flowers of coral diversified the floor.

... A drove of fishes, painted like the rainbow and billed like parrots, hovered up in the shadow of the schooner, and passed clear of it, and glinted in the submarine sun. They were beautiful, like birds, and their silent passage impressed him like a strain of song. (189) With sky, sun, rainbow and birds underwater, all seems to be tipped over as in the mythical Antilles (ant-ilia, isle on the other side), Hesperia (hespera, place of the set sun), or Terra Australia (Land Down Under). "Nemorosa Zacynthos"/New Island seems to be nothing but a mirror - "All-e-same milla" - to the Mediterranean and Western worlds (184). Upon his entering the lagoon, Herrick gratefully drinks of the Lethe waters of forgetfulness: "[i]n the gratified lust of his eye, he forgot the past and the present; forgot . . . f forgot” (189). In the wake of the Discoverers, he hovers to a beatifically cathartic island.

Drinking of the Lethe waters allowed one to be brought back to the world of the living. Ironically enough, to Herrick this means a return to Hell. This is where the hero, while still following in the footsteps of Aeneas and the likes of Bougainville, also starts drastically contrasting them. Upon nearing a Pacific island from whose Happy Groves there "breathed a sense of desertion that was almost poignant" (190), the trio is first met by a woman whose 
"exorbitant stature" evokes the "enormous bulk" (VI: 99) ${ }^{49}$ of Cerberus, warder of the world of Shadows. Their next encounter is a new impersonation of Charon:

Unchallenged [the rower] accosted them, and assailed them with rebuke: "Whosoever thou art, that in harness of war tendest to our streams, haste thee; speak thine errand whence thou standest, and stay thy step!” (VI: 98) ${ }^{50}$

Like Charon, Attwater steering his boat admonishes the trio:

"Stand in for the pier!"...

Mechanically, the orders were obeyed, and the ship berthed; and the three adventurers gathered aft beside the house and waited, with galloping pulses and a perfect vacancy of mind, the coming of the stranger who might mean so much to them. (191)

Only to the bearer of the golden bough will Charon grant access. Likewise, only to the bearer of academic laurels, Oxford-educated Herrick, does Attwater grant his greetings. Like Bougainville's epigraph, Herrick's quoting of Virgil opens the doors to antiquity regained in the Pacific.

But the stern island welcome meted out to the Farallone is a far cry from the buoyant way the Discoverers were hailed and feasted, at least as reported in Bougainville and his counterparts' printed accounts. On "New Cythera," Bougainville says, seafarers were greeted with gifts of a young girl's love: "on every daily stroll our people took in the country . . . the landlords' civility did not stop at offering some slight snack; they offered them young girls"(138). ${ }^{51}$ To the Discoverers' approaching ships, scantily dressed vahine would perform welcoming dances (Figure 15) that the explorers took for invitations to sex - as, they surmised, was the natural way with Tahitian savages. This, writes anthropologist Serge Tcherkezoff, was a cultural misunderstanding: the offerings were invitations to sex, but holy, not ordinary. Indeed, after the first Discoverer, Wallis, had made a deadly display of his 
gunpower, awe-struck Tahitians sought to curry favour from beings they held as half divine. They soon presented the newcomers with virgin girls who were to "urge the gods to come temporarily closer to humans, so that some of their divine fecundity might be captured and the annual seasonal cycle stimulated" (Tahiti 138$).{ }^{52}$

None of these delights awaits the newcomers on the Farallone: indeed, it is quite remarkable that in this Pacific fiction of Stevenson's, sensuous vahine should be so conspicuously absent. Bougainville's brown-skinned "Venus" who unveiled "her celestial shape" to the newcomers is here supplanted by a "woman of exorbitant stature and as white as snow" (190). Only the misunderstanding endures: to the mariners she seems "to be beckoning with uplifted arm" (190). What proves to be a figurehead's frozen gesture is a grotesque parody of graceful Tahitian traditional dances, or aparima. An overpowering white woman now stands in place of lively vahine, a patent symbol of Western supremacy over Pacific islanders. She embodies white arrogance and aggressiveness, standing "hard by the flagstaff" (190) with "her helmeted head tossed back, her formidable arm apparently hurling something" (200). She also calls attention to the artificial and incongruous quality of her presence on the atoll. What should a monstrous fake woman "as white as snow" do on a sun-baked Pacific beach? What has become of the lively vahine of old? Concurrently, why should Attwater be there, too? Further sustaining the misunderstanding, Attwater is fleetingly mistaken for a native islander: "[his] complexion, naturally dark, had been tanned in the island to a hue hardly distinguishable from that of a Tahitian" (192). He is the figurehead's male counterpart, "huge" and belligerent like her, with a Winchester rifle. He has usurped the native "landlords" of their "civility" rites. "The boat was manned with a couple of brown oarsmen in scanty kilts of blue. The speaker, who was steering, wore white clothes, the full dress of the tropics" (191): the steering Attwater has taken the place of the Pacific-colonising semi-god Maui, the mythical founder whose conquering canoes first discovered and settled Pacific archipelagos 
long ago. The new colonising authority is white; he brutally rules over a "brown" people and serves his "private interests" (185), not the Polynesians'. What are Attwater's rights to do so, and to call the island his own? The next question is: what are British, French, German, and American quasi-colonial rights in the Pacific? The answers, which are explicitly spelled out in Stevenson's indicting Footnote to History, are allegorically given through The Ebb-Tide's presentation of Attwater's incipient imprint on New Island.

\section{$\underline{\text { Sombre sortes Virgilianae }}$}

The island's allegorical function is to allow Herrick to complete his katabasis. According to the antique epic scheme, a hero's katabasis leads him to the underworld in order to consult his father's shadow about the future. Then the hero may continue in the living world on a safer basis: this mourning process enables him to move on and fulfil his destiny. Ulysses and Aeneas descend into Hell to seek advice from their fathers. I suggest that so does Herrick, to sound out Attwater, the spirit incarnate of Western commercial, political, and spiritual imperialism. This mourning process might allow him to move on to a next stage postcolonialism.

Attwater's island unmistakably looks like Virgil's sojourn of the dead:

"Ad any deaths?" asked Huish "'ere on the island?"

“Twenty-nine," said Attwater. "Twenty-nine deaths and thirty-one cases, out of thirtythree souls upon the island. - That's a strange way to calculate, Mr Hay, is it not? Souls! ... [T] he house is empty and the graveyard full." (194)

After a guided tour of the cemetery at "the obsequies of day" (205) with "seraph"-like Attwater, Herrick hears “the phantom voice of Davis [call] in his ear: 'There's going to be a funeral"” (206). There seems to be, indeed, "nobody of the living" (VI: 98) on the island. The father figure of Attwater, comparable to Anchises welcoming Aeneas, cajoles the hero home. 
Herrick even very briefly feels he belongs with his own kin: "that he should be accepted as an equal, and the others so pointedly ignored, pleased him in spite of himself” (196). This kinship is confirmed by Davis: "he's your kind, he's not ours" (198). Out-anchising Anchises, this father figure divines all about Herrick - "I knew that you despised yourself" (205); he makes him drop his alias and face his true identity. Attwater also divines Davis and Huish's true nature: "two vulgar wolves" (205). Herrick, who used to vainly try and divine the future from sortes Virgilianae in Tahiti, is awed by Attwater's divinatory powers: "'he saw the whole thing,"” he says to Davis, "'he knows all. That man with the cat knows all; can't you take it in?' . . 'He knows all, he sees through all'” (221). Scholarly Herrick realises that Anchises-like Attwater speaks oracles; untutored Davis does not: “'All what?' asked the captain, visibly discomposed" (222).

And yet the father figure's predictions in The Aeneid and in The Ebb-Tide are quite jarring. Anchises unrolls to his son the vision of a radiant future:

[they] mounted a hillock, whence, in full view, he might ... note the lineaments of them that came.

"Come now, and harken to thy destiny, while my lips rehearse the glory that hereafter shall follow the Dardan line, and thy children's children. . . Look, my son, and know that under [Romulus's] auspices shall glorious Rome bound her empire by earth.” (VI: 106$07)^{53}$

In contrast, the panorama Herrick is given to contemplate is not of a bright future, but of a forlorn past: "rusty tanks," "wrecks," "heaps of lumber," and "old junk" (201), and a cemetery, where "[n]othing grew" (204). In this katabasis, there are no "children's children" to be seen; instead, the ground is strewn with what looks like children's scattered petrified body parts: "the cemetery of the island, a field of broken stones from the bigness of a child's 
hand to that of his head." What Herrick gazes at is the ruins of a collapsed empire, not the seeds of a nascent one. Even the figurehead, a former "defiant deity," is but derelict remains of bygone imperial glory: "a piece of naval sculpture, the figure-head of a ship that had long hovered and plunged into so many running billows, and was now brought ashore to be the ensign of that empty town" (190) (Figure 16). Her arrested gesture may symbolise the end of clichéd South Sea romance: it is fossilised, like conventional R. M. Ballantyne's The Coral Island, Stoddard's South Sea Idylls or Loti's The Marriage of Loti. In Stevenson's eyes, the defiant figurehead and South Sea literature are bygone representations of the Pacific. Her economic and political, their cultural Western hegemony, are here shown to be over.

Neither is there the slightest prospect of any "children's children" stemming from the sole woman alive on the island, the fleeting figure of a Pacific islander. The founding father of Western imperialism will not have his progeny born from a native:

"She is pretty," said Herrick.

"Too pretty," said Attwater. "That is why I had her married. A man never knows when he may be inclined to be a fool about women; so when we were left alone, I had the pair of them to the chapel and performed the ceremony. She made a lot of fuss. I do not take at all the romantic view of marriage," he explained. (210)

It might be argued that Attwater's rejection of a native partner complies with ancient Pacific lore. Indeed, we have seen that in pre-contact islands, foreigners could be coveted as bearers of supernatural fertility powers. Anthropologist Marshall Sahlins confirms that with such quasi-supernatural beings coming "from the beyond," there could be only highly sacred sexual intercourses, no regular, profane, and natural unions (79). This might explain why Attwater will neither "fool about" nor marry a native. In compliance with ancient lore again, he has just grabbed power, an appropriation that has brought "ritual chaos," presumably "until the new king returns to reinstate the tabus, i.e., the social order" (Sahlins 80). Contact did 
bring to the Pacific fundamental chaos, disorder, disease and devastation, and a dramatically new order of things. Likewise, Attwater and his partner, Dr Symonds, impose their own "cosmological order" (Sahlins) and a radically new system upon the havoc they have wreaked - by transplanting islanders and being instrumental in the spread of epidemics. For his "installation rituals" (Sahlins), Attwater displays specifically Western ceremonial symbols, a white tablecloth and wine, instead of the traditional $\operatorname{tapa}^{54}$ and $k a v a,{ }^{55}$ the barkcloth and local drink that were used to consecrate sovereignty. The symbolic value of both barkcloth and kava was "preeminent[ly] feminine," "the highest product[s] of woman's labor, and as such a principal good of ceremonial exchange," because power could only be legitimated through native women and their treatment of "the island's reproductive powers" (Sahlins 86) (Figure 17).

This illuminates Attwater's, and the Discoverers' and the first settlers', fatal disruption of Pacific history. First, tablecloth and wine are products (manufactured, one of them) imported from far-away imperial powers: in no way may they reflect a native woman's fecundity, or the fertility of mother earth in the Pacific. Second, these goods of Attwater's are not of sacred “ceremonial exchange," but of strictly, and explicitly outlined, profane commercial value: “[a] hundred and twelve shillings [a bottle] in London, and the freight to Valparaiso, and on again" (The Ebb-Tide 213). Third, Attwater's "sea and foreign goods" are not purveyed "to the people of the land ... in exchange for indigenous land products" (Sahlins 101); instead, tablecloth and wine contribute to the islanders' servitude: the men "waited deftly, brought on the wines and dishes at a look, and their eyes attended studiously on their master" (The EbbTide 215). The same with the divers' outfits: further instruments of the natives' enslavement, they allow Attwater to have "as many as ten divers going all day long" (210). Fourth, there is no "exchange" to speak of: these "sea and foreign goods" unilaterally serve Attwater's private interests. While he gives the islanders nothing, Attwater nevertheless exploits the products of 
the atoll, a ten-year's accumulation of pearls which he intends to ship off back to the invisible "beyond" from which he has materialised. Fifth, the indigenous products are not even "the agricultural and craft products of the native owners" (Sahlins 101), simply because the islanders are not the native owners of New Island. They were collected by The Trinity Hall, another instrument from the sea that enslaves islanders, from "as far west as the Kingsmills and as far south as Rapa-iti” (The Ebb-Tide 215). They are a motley crowd, a disparate and artificially assembled people made to toil on alien, brutally imposed tasks, to serve foreign interests. This mosaic people may embody imperialism, i.e. territories and peoples conquered and yoked together. In 1842, for instance, France pooled together Pacific peoples as diverse as the Marquesans, the Paumotu, and the Society Islanders, under the banner of Établissements Français du Pacifique. Witness also the successive Berlin Conferences of the 1880s-90s, when Pacific, Asian, and African territories were arbitrarily shared among Western powers, and artificial borders drawn, not heeding whether they were dividing or uniting aboriginal ancestral friends or foes.

As a result, the gap between Anchises's and Attwater's predictions lies between a prolific progeny and sterility. The Aeneid's katabasis forecasts the wedding of the conqueror from the sea with the Italian princess, Lavinia. To secure a fruitful future, there must be some miscegenation, some actual union to the earth that has been claimed. Likewise, in the Pacific of old, "the original transfer of power to the immigrant prince [was] signified by the surrender of a native woman of rank" (Sahlins 86). But in The Ebb-Tide, all "the island's reproductive powers" are discarded or fatally disrupted. Attwater wants no union to a native. The father figure can see no future for himself and his line in the Pacific: "'You see, I may look to make an excellent marriage when I go home"” (210). He belongs to the generations of white men whose stays in the Pacific were short-lived and superficial, like most Discoverers - and like 
Melville's Tomo, Loti, or Stoddard's narrator, who longed to sail back to their motherlands. A mostly obnoxious character, Attwater may illustrate Stevenson's departure from conventional South Sea literature that represents islands as passing exotic intermissions. He may also illustrate Stevenson's postcolonial belief that empires cannot hold. Novelist-anthropologist Stevenson hints that, unless the natives' own rites are allowed to consecrate the presence of foreigners, chaos shall endure. Unless foreigners respect local traditions and cosmological systems, they will remain a sterilely self-centred and severely disruptive presence in the Pacific. Exclusive, brutally and artificially imposed political, economic, cultural, and social Western systems will barren the land and its people. Since there was no going back to precontact times in the Pacific, what remained for a flourishing future might be miscegenation at all levels. ${ }^{56}$

\section{$\underline{\text { The underworld "business and colony" }}$}

At the allegorical time closely following the first fatal impact, when the Pacific islands suddenly became "silent as a grave," New Island had just been hit by a "pestilence" brought in by a tiny white "settlement ... fresh painted, trim and dandy" (The Ebb-Tide 200). The Ebb-Tide's shocking figures, “[t]wenty-nine deaths and thirty-one cases, out of thirty-three souls upon the island," tally with twentieth-century historical reports: the 100,000 estimated inhabitants of Tahiti in 1767 had dwindled to fewer than 10,000 by the mid-nineteenth century (Rallu 222). On Mangareva island in the Eastern Tuamotu, "[t]wo Manga Revan families of the old stock [i.e. about two hundred people] are the lone survivors of a civilization numbering nine thousand souls" (Eskridge 140). Epidemics that were trivial to Westerners proved terminal to non-immune Pacific islanders. Diseases were imported, first by Discoverers, followed closely by merchant ships and whalers, and then by settlers. And very 
soon afterward came "the ravages of alcohol" (Rallu 222), ${ }^{57}$ which led to "the melancholy increase of depravity, and destructive consequences of vice" (Ellis 24).

Yet another fatal factor was "blackbirding" and forced labour. Attwater, the prototype of the first trader and first settler, combines most of these Western evils. He epitomises the havoc wreaked by the original economic and political quasi-colonial settling of the islands. For example, as has been demonstrated by Jolly, "Attwater is a slaver," since his native labourers, collected from all over the Pacific, have no legal contracts to work on a pearl fishery that, itself, has no legal status ("Piracy, Slavery, and the Imagination of Empire" 167). The enslaved islanders lead a life of terror:

As the boy was filling Huish's glass, the bottle escaped from his hand and was shattered, and the wine spilt on the veranda floor. Instant grimness as of death appeared in the face of Attwater; he smote the bell imperiously, and the two brown natives fell into the attitude of attention and stood mute and trembling. There was just a moment of silence and hard looks; then followed a few savage words in the native; and, upon a gesture of dismissal, the service proceeded as before. (215)

Stevenson's postcolonial discourse inverts the precepts of civilisation and savagery: the "imperious" one proves to be "savage."

Attwater's labourers are denied all legal rights, including freedom of speech. This is best illustrated by the embedded tale of Obsequious and Sullens. As Attwater claims, Obsequious and Sullens are "the types themselves detected in the fact" (217) - but not only Bunyanesque "types," as British Attwater would have it: they are also types in the history of the Pacific. They stand for the islanders' utter dismay at the loss of their political, social, economic, and cultural bearings, which Stevenson was an eyewitness to, and compassionately compared to the eighteenth-century Highlanders' under British rule. Here is what Stevenson noted during his stay in the Marquesas in 1888: 
The Marquesan beholds with dismay the approaching extinction of his race. The thought of death sits down with him to meat, and rises with him from his bed; he lives and breathes under a shadow of mortality awful to support; and he is so inured to the apprehension that he greets the reality with relief. He does not even seek to support a disappointment; at an affront, at a breach of one of his fleeting and communistic loveaffairs, he seeks an instant refuge in the grave. Hanging is now the fashion. ... This proneness to suicide, and loose seat in life, is not peculiar to the Marquesan. (In the South Seas 25-27)

Obsequious and Sullens represent two different responses to contact. Obsequious is like the Tahitians after they were attacked by Wallis: "all smiles; he r[uns] to catch your eye," "he talks, and lies, and watches your face to see if he has pleased you" (217). Sullens, on the other hand, is like later Marquesans: he has "a black look" and is "ungraciously obedient." His sullenness is a consequence of white oppression; he reflects the rancour of a downtrodden people. Obsequious or Sullens, each endeavours in his own way to adapt to foreign rules that make no sense to him. When wrongly accused, Sullens is not to question the white man's "regulations": "we allow no explanations; none are received, none allowed to be offered." In such circumstances, like many Pacific islanders, Sullens commits suicide. Contrary to Attwater's judgements, Obsequious has no inkling of the part he has played in his companion's tragedy, because he cannot make head or tail of the white man's rules. About Sullens's hanging, The Ebb-Tide produces a horrid detail: "his tongue was out, poor devil, and the birds had got at him." Sullens's inert tongue, a useless appendix, is a potent symbol of Pacific culture ruthlessly slashed off, of native expression brutally silenced: it speaks of dances prohibited, of welcoming rites usurped. It tells how Pacific culture as a whole was denied, deviated, and very nearly destroyed. The carrion-eaters symbolise "glotophagous" imperialism, as coined by linguist Louis-Jean Calvet (23). Sullens's suicide expresses the fatal 
despair of a censured people. With such gruesome detail and compelling symbolism,

Stevenson obviously means to shock Western readers into censuring quasi-colonial rules, and have them follow Herrick's example:

Herrick sprang to his feet with a shriek and an insensate gesture.

"It was murder,” he screamed. “A cold-hearted, bloody-minded murder! You monstrous being! Murderer and hypocrite - murderer and hypocrite - murderer and hypocrite -" he repeated, and his tongue stumbled among the words. (219)

Herrick does not approve of the founding father of "a colony" in the Pacific. Nor does he adhere to Attwater's “business." He will not be an accessory to the slave trade Attwater's commerce thrives on. Just as he finally resigns from Davis's piratical enterprise, to which he prefers suicide, in the same way, he ignores Attwater's illegally acquired fortune:

"I do not care for pearls. I am very indifferent to all these ..."

“Gewgaws?” suggested Attwater. (210)

Attwater's fortune, based on a slave trade, may symbolise the wealth of the Western nations, which throve on such "gewgaws" as sugar cane and tobacco, grown on a slave trade in the New World that lasted over two centuries. ${ }^{58}$

Thus does Herrick's katabasis prove a successful rite of passage: the foundations of Western empires have been unveiled to him in their political, commercial, and cultural aspects. He violently rejects them in a definitely postcolonial stance. I consequently argue that one of The Ebb-Tide's underlying messages is that the British, French, Germans, and Americans have neither colonial, nor quasi-colonial, rights in the Pacific.

\section{The underworld "mission"}

May Western politics of religious conversion in the Pacific be any more justified? As is evinced by his treatment of missionaries in The Beach of Fales $\bar{a}$ (1893), and in his relations to 
the contemporary LMS, Stevenson could be a supporter, and even an admirer, of missions (Colley 11-42). However, he did realize that early missionaries, too, had brought epidemics to the islands, and had been actively instrumental in censoring native culture, masterminding religious beliefs, and upsetting traditional social structures. Before Stevenson, Herman Melville and Charles Warren Stoddard had already signaled a gap between Pacific missionaries' goodwill and actual evil doings: "Against the cause of missions in the abstract no Christian can possibly be opposed... . Although the object in view be the achievement of much good, that agency may nevertheless be productive of evil" (Melville, Omoo 235). Stevenson's criticism goes further: it both questions "the cause" itself, and dramatises missionary "achievement" in the field. Just as in Hell Aeneas is given a "full view [of] the lineaments of them that came" (VI: 106), Herrick is allowed to view Attwater's missionary work.

What he sees is an "outlaw" (Jolly, "The Ebb-Tide and The Coral Island" 167), a selfstyled missionary like the many who belonged to no church or missionary society, and yet were ardent, sometimes violent, proselytisers to their personally-tailored faiths. Attwater is a fanatic wielding absolute power, and acting as if he were an emissary of God Almighty. Thus, the huge father figure towers above graves "at the obsequies of day" and, in a parody of Doomsday, pronounces judgements profuse with Biblical quotes and racial condescension:

"Some were good, some were bad, and the majority (of course and always) null. Here was a fellow, now, that used to frisk like a dog; if you had called him he came like an arrow from a bow; if you had not, and he came unbidden, you should have seen the deprecating eye, and the little intricate step. Well, his trouble is over now, he has lain down with kings and councillors, the rest of his acts, are they not written in the book of the chronicles? That fellow was from Penrhyn; like all the Penrhyn islanders he was ill to manage; heady, jealous, violent. ... He lies here quiet enough. And so they all lie.” ... 
He stood, in the strong glow of sunset, with bowed head; his voice sounded now sweet and now bitter with the varying sense. (204-05)

Attwater acts like "the angel of the Lord's wrath, armed with knowledge and threatening judgement" (211).

Like Attwater, early missionaries in the Pacific - including official ones - presumed they could tell the natives what was good and evil, on earth and beyond. Like him, they put Pacific islanders "on the rack" (206), prohibiting polygamy and free union, cannibalism and human sacrifices and the worship of ancient pagan gods, nakedness and dances, etc., and enforcing, instead, marriage and baptism, Western clothes, modesty and private property, and regular attendance at Christian services. Ann Colley confirms the early missionaries' enterprises of destruction, citing "the dogged determination of the first London Missionary Society representatives, sent out in 1797 to Tahiti, to wipe out everything that did not conform to its doctrines ... creating a void which they then filled with their own structures and institutions" (75). When Attwater imposes marriage onto an unwilling native woman, he only slightly caricatures missionary imposition: "if a boy and a girl fell in love with each other they must be legally married. And all this must be accomplished almost overnight, when for thousands of years it had been otherwise" (Eskridge 172). Attwater's proselytising demonstrates what Stevenson wrote in 1894 to a prospective missionary, Adelaïde Boodle: "you cannot change ancestral feelings of right and wrong without what is practically soul-murder" (Mehew 593; the italics are Stevenson's).

But as Colley also argues, "[t]hese acts and accounts have a horrifying resilience and reflect awful truths, but they do not represent the whole experience or impact of the missionary presence in the Pacific" (75). To create the character of Attwater, Stevenson may have been inspired by a particular fanatic, Father Laval, a Jesuit who ruled over an Eastern Tuamotu island, Manga Reva, from 1834 to 1871. “A person of no small calibre," Laval came 
to missionary work with a mind "to be . . . canonized by the church for some great mission ... - to save souls for the church [and] to gain some of this pagan wealth in pearls" (Eskridge 142-44). His incentives may be compared to Attwater's:

"What brought you here to the South Seas?" [Herrick] asked presently.

"Many things," said Attwater. "Youth, curiosity, romance, the love of the sea, and (it will surprise you to hear) an interest in missions." (203)

Attwater omits to mention pearls, although he later speaks of "a ten year's accumulation" (210) of them, and concedes: "I made my mission pay" (204). Laval made his mission pay by having thousands of natives literally work to death. To the native king who pleaded for a slackening of labour, he is reported to have answered: "Make them work day and night! Only by such righteous labor can they expatiate the sins of their lustful ancestors!" (Eskridge 17677). In this, he is echoed by Attwater:

“A man has to stand up in God's sight and work up to his weight avoirdupois; then I'll talk to him, but not before. I gave these beggars what they wanted: a judge in Israel, the bearer of the sword and scourge; I was making a new people here; and behold, the angel of the Lord smote them and they were not!" (204)

Like Attwater, Laval was an impenitent murderer:

In 1864 the Comte Emile de la Roncière, governor of Tahiti, demanded: "What sort of government do you call this? Five thousand men and boys dead in ten years, over half the population, from this mad building plan of yours!” (Eskridge 184)

Laval is then said to have made this famous defense:

"True, Monsieur le Comte, they are dead, but they have gone to heaven the more quickly." 
Laval was a fundamentalist; few missionaries went to such murderous extremes. Similarly, Colley stresses that Attwater "exaggerates ... the whole missionary enterprise that had readily violated an island's traditions by attempting too radically and completely to graft itself upon its culture and social system" (40). She is right in insisting on the role many missionaries, even early ones, played in preserving the native culture which, at the same time, they were bringing down. Ellis's Polynesian Researches (1842) is the most notable example of these contradictory compulsions "to study and save what they and others were demolishing" (Colley 75).

Official or not, however, missionaries not only overthrew religious and cosmological orders, they also dismantled political, economic, and social structures in the Pacific. Native chiefs found they were dispossessed of their mystical powers, their mana - "a part of the original divine that gives a chief, or alii, his necessary efficiency" (Tcherkezoff, Faa Samoa $220)^{59}$ - to be left with unsanctified political power only. The missionaries also favoured monetary systems that evacuated gifts - counter-gifts:

The savage no sooner becomes ashamed of his nakedness, than the loom is ready to clothe him; the forge prepares for him more perfect tools and so on until he is dependent on the artefacts and techniques of Europe. ... Through [the missionaries'] efforts the Pacific islanders were integrated into the British commercial system. (Anon., "Review of R. Perceval \&c.” Edinburgh Review 3: 31. Qtd. in James 145)

As a result, it is hard to tell the difference between Attwater's "business, and a colony, and mission" (204). All three pertain to imperialism, as is hinted at by their owners' first names: William, referring to the Norman conquest of England, and John, to the legendary medieval Christian conquest of Asia. To the question: what are British, French, German, and American colonial or quasi-colonial rights in the Pacific, whether political, economic, cultural or spiritual?, this paper suggests that the answer in The Ebb-Tide is: none. Herrick's katabasis 
leads to an encounter with the founding father of religious empires in the Pacific; the outcome is the hero's choice of a postcolonial, and, as I will now try and demonstrate, even preexistentialist, stance.

\section{From the White Man's burden to Sisyphus's}

In terms of a spiritual mission awaiting the hero, there is once again a huge gap between Anchises's and Attwater's predictions. When Attwater thunders: “Thou fool, this night thy soul shall be required of thee" (210), his prophecy only very jarringly echoes Anchises's:

“behold this people, Rome's and thine. Here is Caesar and all Iulus' strain, destined to ascend the great cope of Heaven ... - Caesar Augustus, child of deity, who shall establish again the age of gold in Latium." (VI: 107) ${ }^{60}$

From their mutual sojourns among the dead, the Roman forefather heralds the triumphant return of the hero to the world of the living, ensued by a glorious posterity both on earth and in heaven; in contrast, Attwater portends the hero's departure to yet another world of the dead, an elusive kingdom of Heaven. No radiant future awaits late nineteenth-century Aeneas-like Herrick, neither on earth nor in heaven.

Herrick's response also deviates from the antique model. Ecstatic Attwater delivers oracles:

"I see it, I know it, I put and keep you there, my fingers are on the screws!" said Attwater. "Please God, I will bring a penitent this night before His throne. Come, come to the mercy-seat! He waits to be gracious, man - waits to be gracious!” (206) To which Herrick blankly replies: "I do not believe" (207). Instead of blindly obeying gods, or God, it is Attwater's prophecies he is blind to: 
"Today it groweth and flourisheth; tomorrow it is cut down and cast into the oven. Today it is here and together in this safe; tomorrow - tonight! - it may be scattered. Thou fool, this night thy soul shall be required of thee."

"I do not understand you," said Herrick. (210)

These gaps lie at the basis of The Ebb-Tide's structural variation on The Aeneid's katabasis. There is a critical divide between, on the one hand, imperialist Aeneas "fulfil[ling] the commands of Heaven" (IV: 62) - Virgil repeatedly insists that the hero is but an instrument in the hands of gods: "'the fates [did not] suffer me to be captain of my own life, and at my own will to order my troubles"” (IV: 61); “" not of free will do I follow Italy!”” (IV: 62); "Fate stood in his path, and Heaven sealed his unmoved ear" (IV: 63) ${ }^{61}$ - and, on the other hand, Herrick asserting his atheism and his own free will, and expressing his personal disapproval of the founding father of imperialism. In Stevenson's postcolonial representation, empirebuilding can no longer be construed as a tenet of fate that brooks no disputation. There no longer is any such thing as an absolute decree or a manifest destiny from above that empires shall thrive.

As a consequence, the oracular father figure is unable to answer the hero's fundamental questions -- "“What am I to do?"” (207); "“What must I do?”” (230) -- because father and son stand worlds apart. Attwater seems to be mired in some derelict past, the vestiges of an empire that is no more; and the kingdom of heaven he heralds is nonexistent to atheistic Herrick. Herrick just sticks to the essentials of his own life here below: "“I have nothing left that I believe in except the living horror of myself"' (230).

Ironically enough to twenty-first-century readers, the one who sounds prophetical here is Herrick: in his rejection of Attwater's mysticism, he announces twentieth-century existentialist heroes. Indeed, when Herrick realises that there can be no legitimacy to any of 
the imperialistic enterprises that go rampant on the island, he opts for suicide: his emblematic move may signify that, to his mind, Western presence must be wiped out from the Pacific. It also dramatises "the only really serious philosophical problem . . . : suicide" (15). ${ }^{62}$ Herrick's suicide attempt reveals how imperiously his body clutches at life: "he was aware of an opposition in his members, unanimous and invincible, clinging to life with a single and fixed resolve, finger by finger, sinew by sinew" (228). He prefigures Albert Camus's analysis:

In the way a man clings to his life, there is something stronger than all the world's miseries. The judgement of the body is worth no less than that of the mind and the body balks at self-destruction. (Camus 20-21)

This crucial stage in Herrick's katabasis revealingly occurs in a chapter entitled "The Open Door" as, when he steps through "the open door" of suicide, Herrick finds out who he is fundamentally:

To any man there may come at times a consciousness. . . . It came now to Herrick, with the authority of a revelation. ... There were men who could commit suicide; there were men who could not; and he was one who could not. (228)

Herrick consequently admits he "must go back into the world and amongst men without illusion" (228), "look[ing] forth into a world without any of the lights of hope" (229). It reverberates with Schopenhauer's and Nietzsche's philosophies, and prefigures the existentialist absurd hero:

[The absurd man] only knows that in [his] careful conscience, there is no room for hope. ... The question was to know whether life had to be meaningful to be worth living. It appears that, contrariwise, it will be all the worthier if it is meaningless. . . To live is to make the absurd live. To make it live is first and foremost to stare at it. (Camus 70, 76) Herrick's katabasis has him stare at the absurd and deliver a profession of non-faith: 
I do not believe there is any form of words under heaven, by which I can lift the burthen from my shoulders. I must stagger on to the end with the pack of my responsibility; I cannot shift it; do you suppose I would not, if I thought I could? I cannot - cannot cannot - and let that suffice. (207)

Like Sisyphus, "the useless labourer of hell” (Camus 161), "he must," the narrator repeats after Herrick, "stagger on to the end with the pack of his responsibility" (228). Herrick pushes on for the shore, just as Sisyphus pushes on for the top of the hill:

with an incredible simplicity of submission to ascertained fact, he turned round and struck out for shore. There was courage in this which he could not appreciate... A strong current set against him like a wind in his face; he contended wearily, without enthusiasm ... and Herrick pushed on again for the shore. (228-29)

Sisyphus relentlessly, obstinately rolling his rock uphill encapsulates the absurd, the existentialist philosophy of a man who is responsible for his own destiny and admits there is no hope of a better life. Like Sisyphus, Herrick in Hell embodies the allegorical hero of existentialism-to-be. Herrick's burden is not Kipling's “The White Man's”; it is Camus's Sisyphus's.

What emerges from Stevenson's revisitation of The Aeneid's katabasis is that, because empire-building can no longer be taken for granted, because it is no mission from above, the West's proclaimed manifest destiny to bring spiritual light to benighted savages no longer sustains. Herrick vindicates his right to choose his own destiny, and his katabasis to consult his forefather's shadow enables him to assert his individual freedom of spirit. Herrick prefigures twentieth-century heroes: his is a fight for personal development, not an Empire's. An avant-garde post-colonialist and existentialist, he is not heir to the spirit incarnate of imperialism. 
Herrick does not fulfil the "Destiny" that Mercury-like Davis initially heralds for him; as a matter of fact, at the end of Stevenson's epic, Davis degenerates into a simple-minded religious bigot, and as such, is eventually the only one in the trio who blindly believes Attwater's self-styled prophecies and finds a home in "nemorosa Zacynthos"/New Island. At this ultimate stage, Herrick has mixed feelings for Davis, "part of annoyance, part of amusement, . . . a very mingled mood of humour and pity," even to the point of exasperation: "I never heard such nonsense!" (251). Indeed, to the absurd man, "Christianity is the scandal, ... the sacrifice of the intellect" (Camus 57). Davis has turned into what Herrick calls “"Attwater's spoiled darling and pet penitent"” (252), and he parrots proselytisers: “"O! why not be one of us ? why not come to Jesus right away, and let's meet in yon beautiful land? That's just the one thing wanted; just say, Lord, I believe, help thou mine unbelief!"” As advertised here by Davis, "yon beautiful land" is not Aeneas's promised homeland. Rather, it looks like yet another Terra Australia or El Dorado or Bougainville's Happy Groves, one of those paradises or utopias he, like most Westerners, seems to be in constant quest of in the Pacific. It is a collective whim, and one that Attwater is particularly prone to indeed, at the close of the narration, Attwater is no longer described as a portentous diviner, but as a somewhat diminutive figure who is only glimpsed from a distance. Herrick, in contrast, stands out as an eminently free man; he liberates himself from all father figures, including, at an intradiegetic ${ }^{63}$ level, the uttermost figure of authority: the narrator. A protomodernist character, Herrick leaves Davis's invitation unanswered, and the narration abruptly stops there, in mid-air, inconclusively. In sharp contrast with The Aeneid - which closes on ghastly imperial wars, “"the great agony of thy people"” (VI: 109), ${ }^{64}$ eventually securing Aeneas's founded home - as well as with previous South Sea literature - which had the hero return home - The Ebb-Tide does not conclude. Readers can only surmise what Herrick will do next. But in true existentialist fashion, there is no predication about the hero's 
fate: readers have to "live only with what they know, make do with what is" because "an absurd work of art gives no answers" (Camus 76).

I have tried to demonstrate that The Ebb-Tide revisits The Aeneid's katabasis, not only as a literary reference, but also as a historical and cultural hallmark, a founding text of Western imperialism in Roman antiquity, as well as in the age of Enlightenment and in Victorian times. Looking back to the past serves the "writer of boundaries" (Ambrosini and Dury) to better shape the present and pave the way for the future; indeed, reverberating The Aeneid starts several new modes of writing. First and foremost, postcolonialism. At a literary level, the postcolonial palimpsest calls for conventional representations of the South Seas, themselves Euro-centred reverberations of The Aeneid, to be written over in a fresh fashion. At an economic level, it denounces the unilateral exploitation of island human and sea resources. At political and religious levels, it reveals how fatal to islanders, and to generic Others, imperialist oppression can be. Unlike the horror of imperial wars in Virgil's epic, which is a temporary evil necessary to achieve permanent peace and spiritual harmony in Italy, the murderous chaos described by Stevenson spells the demise of a whole people, with no perspective of a restored order. The antique scheme of a descent into Hell consequently leads the postcolonial hero to indict the father figures of imperial authority. A second new mode of writing is existentialism-to-be. Unlike Virgil's epic hero, who blindly follows the commands of the gods, atheistic Herrick denounces the lie of a manifest destiny that supposedly burdens Western nations with a mission to evangelise. The Ebb-Tide forays into twentieth-century philosophy and, in Hell, Herrick adumbrates the absurd hero, Sisyphus. A third new mode is protomodernism. After challenging figures of literary, political, economic, and spiritual authority, the author finally challenges the narrator's authority. This heralds postmodern writers, who refuse to keep their authority status or to impose a reading line over 
readers, and favour a reading based on each individual's free choice. Postcolonial and protomodern, The Ebb-Tide illuminates a quest for reciprocity and a new relation to the Other. This leads to the last, but not least, mode of writing initiated by Stevenson, what may be called anthropological fiction. The novelist-anthropologist stands out as an advocate of aboriginal culture. He indicates that the West should pay respect to native cosmological order, and even hints that, if The Ebb-Tide's hero were to adhere to any creed at all, it is native Pacific paganism he would convert to: "he could have found it in his heart to regret that [the figurehead] was not a goddess, nor yet he a pagan, that he might have bowed down before her in that hour of difficulty" (200). Stevenson anticipated Claude Levi-Strauss: "Against the theoretician, the observer should always have the last word; and against the observer, the rationalized interpretations of the native" (Levi-Strauss 8).

Using The Aeneid as a hypotext for The Ebb-Tide, the author refrains from concluding and hands his narrative over to the Other. The Ebb-Tide is an open text that may serve as a hypotext to subsequent Pacific narratives: "a text may always conceal another one, and on and so forth, till the end of texts" (Genette back cover). A palimpsest, it gives no answers, but offers a variation on The Aeneid's katabasis turning an encomium into a criticism, and hinting at how literature may make or mar empires.

University of French Polynesia, EASTCO EA 4241 
Notes

${ }^{1}$ See Jolly (South Sea Tales, Stevenson in the Pacific), Colley, Reid, and LargeaudOrtéga ("Stevenson's 'Little Tale' is 'a Library") for more comprehensive studies of Stevenson as an anthropologist.

${ }^{2}$ Like all Stevenson scholars, "I have treated ... The Ebb-Tide as [a] work of Stevenson, without reference to the influence of his collaborator [Lloyd Osbourne], which is anyway ... almost impossible to perceive" (Eigner 99, n. 34).

3 “A palimpsest, literally, is a parchment whose original writing has been scraped off and covered with fresh inscriptions. The original writing, however, having been only partly erased, can still be read through. Figuratively, this shows that any text may conceal another one without hardly ever completely dissimulating it, which calls for the twin reading of - at least - two texts on top of each other, a hypertext and its hypotext" (Genette, back cover, trans. Largeaud-Ortéga).

${ }^{4}$ Katabasis: voyage to the underworld. Etymologically: "stepping downward." ${ }^{5}$ My thanks to Robert Louis Abrahamson for this information and his general support for this paper.

${ }^{6}$ Pages 124, 125, 144, and 202 in the Oxford World's Classics edition (1999). Further references to this text list page numbers only.

${ }^{7}$ Antonomasia: a trope that consists of using a proper noun as a common noun.

${ }^{8}$ [S] ortes Virgilianae: "the practice of seeking guidance or attempting to divine the future by randomly selecting passages from Virgil” (Jolly, South Sea Tales 280, n. 124).

${ }^{9}$ Further references to the English translation list book and page numbers only. “[R]apido pariter cum flamine ... [u]t primum alatis [tetigit] magalia plantis" (Virgile, vol. 1, IV: 241 and 259). Further references to the Latin text list book and line numbers only. My thanks to Marie Leyral for her help with the Latin text. 
10 "Patris magni" (IV: 238).

11 “Naviget!" (IV: 237).

12 “[F]ata" (IV: 340).

13 "[D]ant clara incendia lucem. . . [C] um mihi se, non ante oculis tam clare, videndam obtulit et pura per noctem in luce refulsit alma parens" (II: 569, 589-91).

14 "Nate, .. . [n] on prius aspicies ubi fessum aetate parentem liqueris Anchisem, superet coniunxne Creusa Ascaniusque puer? quos omnis undique Graeiae circum errant acies" (II: 594-99).

15 “[O]bmutuit amens," "atque animum nunc huc celerem nunc diuidit illuc in partisque rapit uarias preque aomina uersat," "quid agat ?" (IV: 279, 285-86, 283)

16 "Umbrarum . . locus" (VI: 390).

17 “"[C] um tabida membris corrupto caeli tractu miseranque uenit, . . . [l]inquebant dulcis animas aut aegra trahebant corpora" (III: 137-41).

18 “[T] um mihi caeruleus supra caput astitit imber noctem hiememque ferens et inhorruit unda tenebris. Continuo uenti uoluont mare magnaque surgunt aequora, dispersi iactamur gurgite uasto; inuoluere diem nimbi et nox umida caelum abstulit" (III: 194-99). 19 “[E]rrore” (III: 181).

20 “Celaeno, infelux uates," "Furiarum ego maxima pando," "dira fames," "nostraeque iniuria caedis ambesas subigat malis absumere mensas" (III: 245-46, 252, 256, 256-57). 21 “Portitor . . . terribili squalore Charon, cui plurima mento canities inculta iacet, stant lumina flamma, sordidus ex umeris nodo dependet amictus" (VI: 299).

22 "Umbrarum hic locus est, somni noctisque soporae; corpora uiua nefas Stygia uectare carina" (VI: 390-91).

23 “"[T]ecum me tolle per undas, sedibus ut saltem placidis in morte quiescam"” (VI: 370$71)$. 
24 ““[D]ead reckoning,' originally 'ded.' (from ‘deduced') reckoning; estimating a ship's position using only speed and course steered from the last observed position" (Jolly, South Sea Tales 283, n. 158).

25 Trans. Largeaud-Ortéga.

${ }^{26}$ It must be remembered that the real discoverers of the Pacific Islands were not Europeans, but Pacific Islanders originally sailing from South-East Asia.

${ }^{27}$ The Discoverers paved the way for imperialism. In 1867, Wallis claimed possession of Tahiti, which he named "The Island of George III," and in 1768, Bougainville wrote an "Act of Possession" of the same island in the name of King Louis XV. The British exploration of the South Seas was a deliberately conceived and executed imperial gambit. Voyages were disguised as projects of scientific curiosity, but in fact paved the way for mercantile imperialism and territorial expansion. This effort was enabled and accompanied by colonialism in the domains of culture and knowledge, thought to emerge from a consistent European ideology now often characterised as Enlightenment rationalism. (Lamb, Smith, and Thomas xvi)

28 "We tenant the shady groves, and dwell pillowed on the velvet banks, or in the meadows fresh with running brooks." Trans. Jackson.

${ }^{29}$ All translations of Bougainville by Largeaud-Ortéga.

30 “[F]ortunatorum nemorum” (VI : 639).

31 Trans. Largeaud-Ortéga.

${ }^{32}$ See Tcherkézoff, Tahiti 7.

${ }^{33}$ The Falesā spelling is deliberate. See Largeaud-Ortéga, "Stevenson's 'Little Tale' is 'a Library."”

${ }^{34}$ Vahine: proto-Polynesian for woman. 
${ }^{35}$ Loti's The Marriage of Loti (1879) also presents Papeete as a disease-ridden place, an evil environment for young girls, but in a very different mode. In contrast with The EbbTide, The Marriage of Loti maintains the antique representation of an idyllic Pacific world. As Jolly points out, "The Marriage of Loti is . . . an elegiac acceptance that paradise must be lost. Viaud-Loti mourns the effects of the white man's presence in the Pacific, but does not criticize them" ("South Sea Gothic" 44).

${ }^{36}$ Beachcomber: "contemptuous term for a white man with no visible means of support, existing on the fringes of white society and living by charity, odd jobs, or more disreputable means in Pacific ports" (Jolly, "Introduction" to South Sea Tales 265, n. 30.) The word beachcomber seems to have been published first in Melville's Omoo (1847). Melville himself was a beachcomber on the islands of Nuku Hiva, Tahiti, and Eimeo. His Pacific fiction, however, remains in the line of the literary tradition set by Bougainville, adhering to phantasmagorial representations of Pacific islands. "[In 1879,] the themes of the Polynesian paradise and paradise lost had been staple elements of Pacific travel writing for over a hundred years, and both the tropical idyll and the pastoral contrast between urban corruption and natural innocence had featured strongly in Melville's Typee and Omoo" (Jolly, "South Sea Gothic" 31). The same applies to another successful American writer and beachcomber of the time, Stoddard, author of South Sea Idylls (1873). See Largeaud-Ortéga, "Îles mythiques."

${ }^{37}$ It may seem paradoxical to argue that Stevenson depicted Pacific otherness through white men when, unlike Bougainville, he did see the natives as others and not as white men's reflections. Stevenson was indeed acutely sensitive to the islanders' plight under quasi-colonial rule, as is made clear in his historical survey of Samoa, A Footnote to History (1893), his several "Letters" to the Times (1889-93), and previous Pacific fiction like "The Bottle Imp," "The Isle of Voices," and The Beach of Falesā (1893), which 
denounce abusive white hegemony in the Pacific. The answer to this paradox is that these previous writings had had little impact at home.

${ }^{38}$ Isocolon: repetition of phrases of equal grammatical structure.

${ }^{39}$ Anaphoric: repetition of a word at the beginning of a clause, line, or sentence.

${ }^{40}$ Auxesis: arrangement of clauses in order of increasing dramatic effect.

${ }^{41}$ See Sandison 317-35 for the relativity of realism in The Ebb-Tide.

${ }^{42}$ Analepsis: return into the past.

43 Trans. Largeaud-Ortéga.

${ }^{44}$ Hyperonym: generic term.

45 "This naming ... places the colony in the same imperial imaginary, or imaginary imperium, that connected the Roman Empire to the British Empire through the study in classical literature and underwrote the education of Britain's imperial administrators" (Jolly, "Piracy, Slavery, and the Imagination of Empire" 168)

46 There had been fleeting contacts from the seventeenth-century onward, but no settlement in Pacific islands. See James.

${ }^{47}$ This allegorical similitude does not take into account the geological difference between high island Tahiti and low atoll New Island.

48 "[D]euenere locos laetos et amoena uirecta fortunatorum nemorum sedesque beatas" (VI: 638-39).

49 “Cerberus haec ingens latratu regna trifauci personat aduerso recubans immanis in antro" (VI: 417).

50 “[P]rior adgreditur dictis atque increpat ultro: 'Quisquis es, armatus qui nostra ad flumina tendis, fare age quid uenias, iam istinc et comprime gressum"' (VI : 387-89).

51 Trans. Largeaud-Ortéga.

52 Trans. Largeaud-Ortéga. 
53 “"[T] umulum capit unde omnis longo ordine posset aduersos legere et uenientum discere uoltus. 'Nunc age, Dardaniam prolem quae deinde sequatur gloria, . . . nepotes . . . En huius, nate, auspiciis illa incluta Roma imperium terris"” (VI: 754-57, 781-82).

${ }^{54}$ Tapa: Tapa is a piece of barkcloth that was ritually made by women: they would beat the bark of a tree for days into a very thin piece of clothing which was only exhibited on ceremonial occasions. Such an occasion is narrated in Stevenson's The Beach of Falesá (Largeaud-Ortéga, "Stevenson's 'Little Tale' is 'a Library”" 124).

${ }^{55}$ Kava: "the pepper plant piper methysticum, the root of which was used to prepare a drink of great social and ceremonial significance in Polynesia" (Jolly, South Sea Tales 271, n.79). It was chewed by young virgins and spat back into a kava bowl for men to drink in sacred ceremonies. It is mentioned in Stevenson's “The Bottle Imp." See Largeaud-Ortéga, Ainsi Soit-Île 237-38.

${ }^{56}$ Unlike Attwater, Wiltshire in The Beach of Falesā marries an islander and will not sail back to Europe. Their mixed-raced children embody a viable future in the Pacific, however hazy. See Largeaud-Ortéga, “Stevenson's 'Little Tale' is 'a Library."” 57 Trans. Largeaud-Ortéga.

${ }^{58}$ See Jolly, "Piracy, Slavery, and the Imagination of Empire" for a comprehensive study of piracy (including unofficial missions and slavery) in The Ebb-Tide.

59 Trans. Largeaud-Ortéga.

60 “"Huc geminas nunc flecte acies, hanc aspice gentem Romanosque tuos. Hic Caesar et omnis Iuli progenies magnum caeli uentura sub axem. . . Augustus Caesar, diui genus, aurea condet saecula qui rursus Latio regnata"' (VI : 788-94). 61 "[I] ussa . . . diuom exsequitur," "si fata meis paterentur ducere uitam auspiciis et sponte mea componere curas," "Italiam non sponte sequor," "fata obstant placidasque uiri deus obstruit auris" (IV: 396, 340-41, 361, 440). 
62 This quote from Camus and the following ones are translated by Largeaud-Ortéga.

${ }^{63}$ At the intradiegetic level is the narrating voice, as opposed to the metadiegetic level, where are the narrated characters. See Genette.

64 “"[I]ngentem luctum . . tuorum”, (VI: 868)

\section{Works Cited}

Ambrosini, Richard, and Richard Dury, eds. Stevenson, Writer of Boundaries. Madison: U of Wisconsin P, 2006.

Balfour, Graham. The Life of Robert Louis Stevenson. 2 vols. London: Methuen, 1901.

Ballantyne, R. M. The Coral Island. New York: Dutton, 1849.

Barthes, Roland. L'Ancienne Rhétorique. Aide-Mémoire, in Communications. Tome 16. Paris: Seuil, 1970.

Bougainville, Louis-Antoine de. Voyage autour du Monde par la Frégate du Roi La Boudeuse et la Flûte l'Etoile (1767-68). 1771. Paris : La Découverte Poche, 1997.

Calvet, Louis-Jean. Linguistique et Colonialisme. 1974. Paris : Petite Bibliothèque Payot, 2002.

Camus, Albert. Le Mythe de Sisyphe. Paris: Gallimard, 1942.

Colley, Ann. Robert Louis Stevenson and the Colonial Imagination. Farnham: Ashgate, 2004.

Commerson, Philibert de. Lettre de Monsieur de Commerson, docteur en médecine et médecin botaniste du Roi à l'Isle de France, le 15 février 1769. Sur la découverte de la Nouvelle-Cythère ou Tahiti, (pub. Mercure de France, November 1769, 197-205, qtd. in Voyage autour du Monde par la Frégate du Roi La Boudeuse et la Flûte l'Etoile (1767-68), by Louis Constant, Introduction to Voyage autour du Monde par la Frégate du Roi La Boudeuse et la Flûte l'Etoile (1767-68). 1771. Paris: La Découverte Poche, 1997. 
Eigner, Edwin. Robert Louis Stevenson and Romantic Tradition. Princeton: Princeton UP, 1966.

Eliade, Mircea. Mythes, Rêves et Mystères. Paris: Folio essais, 1957.

Ellis, William. Polynesian Researches During a Residence of Nearly Eight Years in the

Society and Sandwich Islands. 1842. 3rd ed. Rutland: Charles E. Tutte, 1977.

Eskridge, Robert Lee. Manga Reva, The Forgotten Islands. 1931. Honolulu: Helen Eskridge

Rodman Mutual Publishing of Honolulu, 1986.

Genette, Gérard. Figure III. Paris: Seuil, 1972.

_. Palimpsestes, La littérature au second degré. Collection Poétique. Paris: Seuil, 1982.

Hawkesworth, John. An Account of the voyages Undertaken by Order of Her Present Majesty for Making Discoveries in the Southern Hemisphere and Successively Performed by Commodore Byron, Captain Wallis, Captain Cateret and Captain Cook, in the Dolphin ..., drawn up from the Journals. 1773.3 vols. London: W. Stratham, 1982.

James, Lawrence. The Rise and Fall of the British Empire. London: Abacus, 1997.

Jolly, Roslyn. "The Ebb-Tide and The Coral Island." Scottish Studies Review 7.2 (Autumn 2006): 79-91.

. Introduction. South Sea Tales. Oxford: Oxford World's Classics, 1999.

Transition: 1880-1920 11 (2004): 28-50.

_. "Piracy, Slavery, and the Imagination of Empire in Stevenson's Pacific Fiction."

Victorian Literature and Culture 35.1 (March 2007): 157-73.

_. "Robert Louis Stevenson and Samoan History: Crossing the Roman Wall." Crossing Cultures: Essays on Literature and Culture of the Asia-Pacific. Ed. Bruce Bennett, Jeff Doyle, and Satendra Nandan. London: SKOOB Books, 1996. 
. "South Sea Gothic: Pierre Loti and Robert Louis Stevenson.” English Literature in Transition, 1880-1920 47.1 (Winter 2004).

. Robert Louis Stevenson in the Pacific: Travel, Empire, and the Author's Profession.

Farnham: Ashgate, 2009.

Lamb, Jonathan, Vanessa Smith, and Nicholas Thomas, eds. Exploration and Exchange, A

South Seas Anthology 1680 - 1900. Chicago: U of Chicago P, 2000.

Largeaud-Ortéga, Sylvie. Ainsi Soit-île. Littérature et Anthropologie dans les Contes des

Mers du Sud de Robert Louis Stevenson. Paris: Honoré Champion, 2012.

__. "Îles mythiques: les archipels de la Société et des Tuamotu dans la littérature anglophone de la fin du XIX ${ }^{\mathrm{e}}$ siècle." 5000 Ans de Culture Ultramarine Pacifique. Ed. Serge Dunis. Tahiti: Haere Pō, 2010.

_. 'Stevenson's 'little tale' is 'a library': an anthropological approach to The Beach of Falesā." Journal of Stevenson's Studies 6 (2009): 117-34.

Lévi-Strauss, Claude. Structural Anthropology. 1960. Trans. Claire Jacobson and Brooke Grundfest Schoepf. New York: Basic Books, 1999.

Loti, Pierre. Le Mariage de Loti. Paris: Flammarion, 1879.

Malinowski, Bronislaw. Les Argonautes du Pacifique Occidental. Paris: Gallimard, 1922.

Mehew, Ernest, ed. Selected Letters of Robert Louis Stevenson. New Haven: Yale UP, 1997.

Melville, Herman. Omoo. 1847. Evanston: Northwestern UP, 1999.

_. Typee. 1846. Oxford: Oxford UP, 1996.

Menikoff, Barry. “'These problematic shores': Robert Louis Stevenson in the South Seas.” English Literature and the Wider World, The End of the Earth 1876 - 1918. Ed. Simon Gatrell. Vol. 4. London: Ashfield, 1992.

Naugrette, Jean-Pierre, trans. and preface. Robert Louis Stevenson. Paris: Le Creux de la Vague, GF Flammarion,1993. 
Rallu, Jean-Louis, Les Populations Océaniennes aux XIX et XX $X^{e}$ siècles. Paris: Institut national d'études démographiques, PUF, 1990.

Reid, Julia. Robert Louis Stevenson, Science, and the Fin de Siècle. New York: Macmillan, 2006

Sahlins, Marshall. Islands of History. 1885. Chicago: U of Chicago P, 1887.

Sandison, Alan. Robert Louis Stevenson and the Appearance of Modernism, a Future Feeling. Houndmills: Macmillan, 1996.

Stevenson, Robert Louis. The Beach of Falesá. 1893. South Sea Tales, Oxford: Oxford World's Classics, 1999.

__. "The Bottle Imp.” 1893. Island Nights' Entertainments. London: Cassell. South Sea Tales. Oxford: Oxford World's Classics, 1999. A Footnote to History. 1893. Auckland: Pasifika, 1996. In the South Seas. 1896. London: Penguin, 1998. . “The Isle of Voices." 1893. Island Nights' Entertainments. London: Cassell. South Sea Tales. Oxford: Oxford World's Classics, 1999.

. "Mr. R. L. Stevenson on Reading and Literature: An Interview.” Argus (Melbourne) 6 May 1893: 4.

Stevenson, Robert Louis (in collaboration with Lloyd Osbourne). The Ebb-Tide: A Trio and a Quartette. 1894. London: Heinemann \& Kimball; Edinburgh: Edinburgh UP, 1995. South Sea Tales. Oxford: Oxford World's Classics, 1999.

Stoddard, Charles Warren. South Sea Idylls. 1873. New York, Scribners’s Sons, 1892.

“Sundowner.” London: European Mail, 1897.

Tcherkezoff, Serge. Faa Samoa, une Identité Polynésienne. L'Anthropologie comme Dialogue Culturel, Paris, L’Harmattan, Connaissance des Hommes, 2003. 
. Tahiti - 1768. Jeunes filles en pleurs. La face cachée des premiers contacts et la naissance du mythe occidental. Papeete: Au Vent des Îles, 2004.

Virgil. The Aeneid. 29-19 BC. Trans. from Latin and turned into English prose by John Jackson. 1908. Hertfordshire: Wordsworth Classics, 1995.

Virgile. Énéide. Bilingual ed. Trans. from Latin and turned into French prose by Jacques Perret. 3 vols. Paris: Les Belles Lettres, 2002. 